\title{
BELTÉRI WI-FI JELERŐSSÉG FELTÉRKÉPEZŐ MOBIL ROBOT TERVEZÉSE
}

\author{
Somosi Gábor László \\ hallgató, Miskolci Egyetem, Automatizálási és Infokommunikációs Intézet \\ 3515 Miskolc, Miskolc-Egyetemváros, e-mail: somosi.gabor.laszlo@student.uni-miskolc.hu \\ Pintér Judit Mária \\ adjunktus, Miskolci Egyetem, Automatizálási és Infokommunikációs Intézet \\ 3515 Miskolc, Miskolc-Egyetemváros, e-mail: pinterjm@uni-miskolc.hu
}

\begin{abstract}
Absztrakt
A cikk egy autonóm Wi-Fi jelerösség feltérképezö robot tervezését részletezi. Szó esik benne a Wi-Fi jelerösségének méréséröl, a mérés során vizsgált paraméter tulajdonságairól és értelmezésének módjáról. A robot tervének részletezése elött bemutatásra kerülnek a vele elvégzendö jelfeltérképezési folyamatok, a robot elvárt funkciói és azok megvalósitása. A cikk központi témájául szolgáló terv két nagyobb fejezetben van ismertetve. A publikáció elsö részében a robot fizikai felépitését alkotó fontosabb alkatrészek kerülnek bemutatásra, azok funkcióival, felhasználásuk okaival és módjával, valamint elönyeikkel és hátrányaikkal. A második részben pedig a robot müködéséhez szükséges programok és azok alapjai kerülnek részletezésre.
\end{abstract}

Kulcsszavak: robot, Wi-Fi, jelerösség, navigáció, hötérkép

\section{Abstract}

The following article details the design of an autonomous Wi-Fi signal strength mapping robot. To begin with, it briefly describes a method of Wi-Fi signal strength measurement, as well as the properties of the parameter that is measured during said method and the correct interpretation of the aforementioned parameter. Afterwards, the signal mapping processes which the robot has to perform are presented, along with the robot's required functions and the implementation of said functions. The design itself, which is the focus of the article is detailed in two larger chapters. In the first major chapter, the components which make up the physical structure of the robot are introduced, along with their respective functions, the reason and method of their utilization and their advantages and disadvantages. The second major chapter details the basics of the programs which operate the robot.

Keywords: robot, Wi-Fi, signal strength, navigation, heatmap

\section{Bevezetés}

Gyakran tapasztalhatjuk, hogy a Wi-Fi eléréssel rendelkező épületek és terek lefedettsége nem megfelelő: azokat bejárva számos ponton elgyengülhet a jel, vagy akár teljesen meg is szakadhat a kapcsolat. Annak érdekében, hogy a lefedettséget egy adott területen javítani tudjuk, fel kell térképeznünk ott a Wi-Fi jelek erösségét.

A jelek feltérképezésére több alternatíva is található, mint például a telefonos alkalmazások, a számítógépes programok, vagy a kifejezetten erre a célra kifejlesztett jelerősség mérő eszközök. Azonban ezen megoldások vagy csak az időben képesek rögzíteni az általuk mért értékeket, aminek 
következtében a felhasználónak a vizsgálat mellett önállóan kell feljegyeznie, hogy a tér adott pontjaiban mekkora volt a jelerösség, vagy egy adott terület teljes feltérképezése közben, annak bejárásához az eszközök mérete miatt jelentős munkára van szükség.

Ezen két hátrány kiiktatását, mint két követelményt szem előtt tartva került az autonóm jelfeltérképező robot megtervezésre. A robot ugyan csak egy-másfél óráig képes szünet nélkül üzemelni, az önálló müködéshez szükséges akkumulátoros megvalósítás miatt, ellenben az előzőekben megfogalmazott két alapvető követelménynek eleget tesz. Mindemellett, a robot által készített, és az első követelménynek eleget tevő hőtérkép segíti a gyüjtött adatok egyszerü értelmezését, valamint az autonóm müködés és a kis méret lehetővé teszi a veszélyes vagy nehezen elérhető területek feltérképezését is.

\section{A jelerősség mérés alapja}

A Wi-Fi jelek erőssége a vevő modulok által rögzített RSSI (Received Signal Strength Indicator) paraméter értékéből kapható meg, mivel az RSSI megmutatja, hogy egy adó antennától megfelelően nagy távolságra levő referencia pontban mekkora az elektromos mező nagysága. A Wi-Fi esetében ez az érték közvetlenül a jel relatív jelerősségét jelenti, így a mért érték minél nagyobb, a jel annál erősebb. Egyes eszközöknél a mért RSSI értéke negatív, ebben az esetben minél kevésbé negatív az érték, annál erősebb a jel.

A paraméter mértékegysége $\{\mathrm{dB}\}$, mivel azonban a vizsgálandó jelek erőssége ezzel a mértékegységgel a nullához közeli értékeket jelentene, így általánosan elfogadott, hogy az értékeket $\{\mathrm{dBm}\}$-ba átváltva fejezzük ki, amely esetben a jel elektromos teljesítményét $1 \mathrm{~W}$ (Watt) helyett 1 mW(milliWatt)-ra vonatkoztatjuk. A mért értékek megfelelő leolvasásához továbbá fontos megjegyezni, hogy az értékek változása a jel erősségéhez képest nem lineáris, hanem logaritmikus, tehát $\pm 10 \mathrm{dBm}$ változás a jel erősségének tízszeres növekedését vagy csökkenését jelzi [1].

Fontos, hogy a jelerősség mérés elvégzéséhez vizsgálni kívánt RSSI paraméter értékét a gyakorlatban értelmezni tudjuk. Az RSSI értéke (amennyiben a kapott érték negatív) leggyakrabban a -30 dBm és $90 \mathrm{dBm}$ értékek által alkotott skálán mozog, ahol a $-30 \mathrm{dBm}$ a kitünő, még a $-90 \mathrm{dBm}$ a zajszint közelében mozgó jelerősséget jelenti. A mindennapi életben egy jó minőségü, erős Wi-Fi kapcsolat esetén a jel RSSI paraméterének értéke -67 dBm [2].

\section{A jelerősség mérés megvalósítása}

Az előzőekben részletezett paraméter megfelelő mérését, és a mért adatok kiértékelését a tervezett autonóm jelfeltérképező robot végzi majd el.

A robotra felszerelt Wi-Fi modul képes az összes, számára elérhető hálózatnak az adott pozícióban mérhető RSSI paraméterét visszaadni. A modul folyamatosan képes a jel erősségét figyelni, az általa mért érték pedig soros kommunikáción keresztül, AP (Access Point) parancsok segítségével lekérhető. Az értékeket a modul maga nem tartja számon, azok rögzítéséhez egy tőle különálló eszköz szükséges. A fejlesztés alatt álló roboton ez az eszköz egy mikrovezérlő, amely az adatokat a rajta futó program alapján, időszakosan rögzíti, majd ezeket további feldolgozásra - a hőtérkép elkészitéséhez - egy számítógépnek küldi tovább. Azt, hogy a paraméter értékét milyen időközönként rögzíti a mikrovezérlö, a rajta futó programon keresztül befolyásolhatjuk. Amennyiben fontos, hogy a jelerősség változások minél részletesebben nyomon követhetőek legyenek, úgy az értékek rögzítése történhet másodpercenként is. 
Annak érdekében, hogy a felhasználó a mérés során ne csak a kapott adatok értékét, és rögzítésük időpontját, hanem azokkal együtt a rögzítés helyét is megkapja, a robot egy hötérképet készít, amely ezen három adatot egy könnyen érthető, és gyorsan leolvasható módon tartalmazza. A hőtérképhez szükséges mérési pozíciók meghatározásához a robot a számítógépe által generált navigációs térképen tartja számon a rögzítés pillanatában elfoglalt helyet. A hőtérkép elkészítése során a robot számítógépe minden jelerősség adatot, azok rögzítésekor, a robot által elfoglalt térkép pozícióhoz rendeli hozzá.

A mérés megfelelő elvégzéséhez a robotnak a kijelölt területet be kell járnia, csak így tudja a hőtérképet elkészíteni. Ennek kivitelezéséhez, a robot kétféle módon tud a területen közlekedni: autonóm navigációval vagy távirányítással.

Elsődlegesen, a robot az autonóm navigációt alkalmazza. Ennek során, a robot számítógépén futó program (a hőtérkép készítése mellett) egy navigációs algoritmus segítségével járja be a számára elérhető területet. A navigációhoz a területről előre nem szükséges térkép, a robot azt a helyszín bejárásakor készíti el.

A távirányítással történő mozgás abban az esetben hasznos, ha csak egy adott helyet szándékozik a felhasználó megvizsgálni, vagy ha a mérés befejezésekor a robotot egy adott helyre akarja eljuttatni. Ahhoz, hogy a távirányításhoz ne legyen szükséges a felhasználó számára, hogy a robotot szabad szemmel is lássa, egy kamera kerül a robot elejére, amelynek videofelvételét a már említett számítógép dolgozza fel, és teszi elérhetővé a felhasználó számára.

\section{A robot rendszerének vázlata}

A tervezett jelfeltérképező robot rendszerének egyszerü, könnyen áttekinthető vázlatát az 1. ábra mutatja.

Feltérképező robot

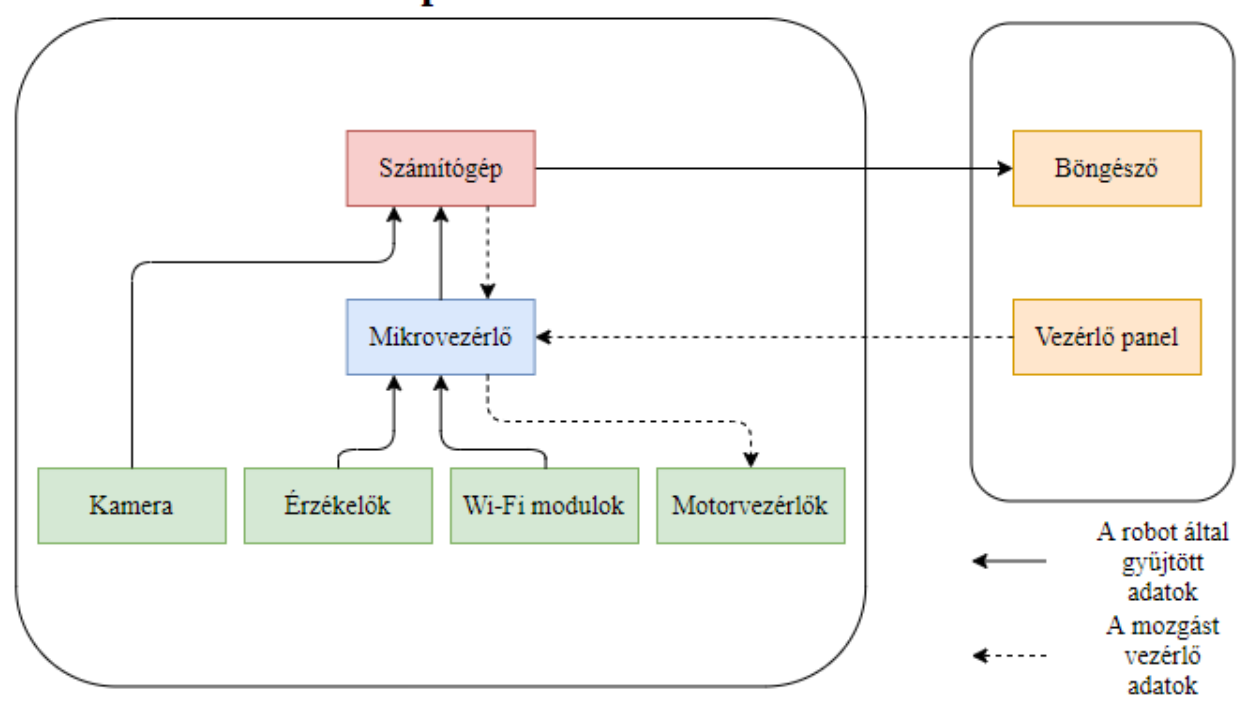

1. ábra. A robot rendszerének vázlata

A felhasználói felület két elemből áll: a böngészőből és a vezérlő panelból. A felhasználó a böngészőn keresztül láthatja a roboton levő kamera által készített képet, az akkumulátorok töltöttségi szintjét és a folyamatosan frissülő hőtérképet. A vezérlő panel segítségével indíthatja el és állíthatja meg 
a jelerősség mérést, valamint engedélyezheti és tilthatja le a robot mozgását. A vezérlőpanelon emellett a robot irányításának módja (autonóm navigáció vagy távirányítás) is kiválasztható, távirányítás esetén pedig a robot szintúgy a panellal vezérelhető. A panel és a robot közti kapcsolat Bluetooth kommunikációval valósul meg. A robot rendszerének, az ábrán látható módon két fó eleme van: a mikrovezérlő és a számítógép. A mikrovezérlő gyüjti az érzékelők és a Wi-Fi modulok által mért adatokat, majd ezeket alap szintủ feldolgozás után átadja a számítógépnek. A számítógép a kapott adatok alapján elöállítja a terület térképét és a hőtérképet, valamint feldolgozza a távirányításhoz szükséges kamera képét. A hőtérképet, a kamera képét és az akkumulátorok töltöttségi szintjét egy webszerver segítségével, a böngészőben teszi a felhasználó számára elérhetővé. Autonóm navigáció esetén a mikrovezérlő a számítógéptől, még távirányítás esetén a vezérlő paneltól kapott adatok alapján müködteti a motorvezérlő áramköröket.

\section{A robot felépítése}

A jelfeltérképező robot rendszerének leglényegesebb alkotóelemei a következők:

- A 3D nyomtatással készült váz,

- a CY8CKIT-059 fejlesztöpanel,

- a Raspberry Pi 4B számítógép,

- a Raspberry Pi Kamera Modul V2,

- az ESP07 Wi-Fi modul,

- az ultrahangos távolságérzékelők,

- az MPU-9250 IMU szenzor,

- és a HC-05 Bluetooth modul.

\subsection{A robot váza}

A jelerősség feltérképező robot vázát az alapul szolgáló, előzetesen elkészített robot adja. A váz és a kerekek, a Magyarok a Marson versenyre, annak követelményeinek megfelelöen készültek el, 3D nyomtatással. A nyomtatáshoz használt múanyag PET-G típusú, amely melegen könnyen, kis energiaigénnyel megmunkálható, valamint a robot funkciójának megfelelő mechanikai jellemzőkkel rendelkezik. A nyomtatás során az alkatrészek kitöltési tényezője $20 \%$-os volt, amely lehetővé tette, hogy a készített elemek elég merevek és ellenállóak legyenek, amellett, hogy a nyomtatás során felhasznált anyagmennyiség költsége megfizethető maradt. A nyomtatáshoz szükséges tervek a 3D Builder fejlesztőkörnyezetben készültek el, amellyel a Windows 10-es operációs rendszer alapvetően rendelkezik.

A robot vázára négy darab léptetőmotor van rögzítve csavarok segítségével. A 28byj léptetőmotorok alapvetően unipoláris kialakításúak, azonban annak érdekében, hogy vezérlésük egyszerübb legyen, és hogy nagyobb sebességre legyenek képesek, bipolárisra lettek átalakítva. A négy motor meghajtásáért két A4988-M típusú bipoláris léptetőmotor meghajtó modul felel. A modulok vezérlő jeleit a PSoC 5LP mikrovezérlő adja a vezérlő panelról kapott információk alapján.

A jelfeltérképező robothoz a már rendelkezésre álló motorok és meghajtó modulok felhasználására azért került sor, mert azok képesek biztosítani a kerekek számára, a jelenleg tervezett felhasználási környezetekben szükséges nyomatékot és sebességet. A felhasznált kerekek kialakítása lehetővé teszi az általánosan előforduló akadályok leküzdését, valamint a leggyakrabban előforduló beltéri padlózatokon való csúszás-, és elakadásmentes közlekedést. A már rendelkezésre álló vázon pedig a jelfeltérképező robothoz felhasználni kívánt összes elem megfelelően elfér. 


\subsection{A CY8CKIT-59 fejlesztőpanel}

A roboton a CY8CKIT-059 fejlesztőpanel részeként, a Cypress által fejlesztett CY8C5888LTI-LP097 $P S o C$ található, amely a $P S o C 5 L P$ család egyik tagja. A fejlesztőpanel egy alacsony árú, breadboardkompatibilis kártya, amely a rajta levő mikroprocesszor minden I/O portjához megfelelő hozzáférést biztosít. A robot részeként a mikrovezérlő a Bluetooth kommunikáció lebonyolításáért, az akkumulátor töltöttségi szintjének figyeléséért, a kapott navigációs adatok feldolgozásáért, a motorvezérlő áramkörök megfelelő vezérléséért, valamint a robotra szerelt egyéb szenzorok müködtetéséért és adataik feldolgozásáért felel.

A mikrovezérlő több analóg-digitális és digitális-analóg átalakítóval, GPIO porttal és időzítő/PWM blokkal rendelkezik, melyek közül a robot megvalósításához egy SAR analóg-digitális átalakító, egy PWM blokk, valamint több, mint 17 GPIO port kerül felhasználásra.

A $P S o C$ platform egyik alapvető tulajdonsága, hogy konfigurálható analóg és digitális blokkokkal rendelkezik. A digitális blokkok használatával a felhasználó 16-, 24-, vagy 32-bit széles logikai jeleket generálhat, még az analóg blokkok segítségével összetett analóg jelek feldolgozása is lehetséges. Ezen blokkok közül több is felhasználásra kerül a mikrovezérlőn futó programban, föként a különböző szenzorokkal való kommunikáció megvalósításához [3].

A jelerősség mérés és navigáció közben felmerülő egyszerü feladatokat, mint a szenzorok jelének feldolgozása és a távirányítás megvalósítása, a CY8C5888LTI-LP097 mikrovezérlő megfelelően képes elvégezni. A fejlesztőpanel kis mérete, és alacsony ára miatt ideális mikrovezérlő a jelerősség mérő robotban való felhasználásra. Előnye továbbá, hogy az ezen feladatokat ellátó müködése közben áramfelvétele kifejezetten alacsony, így az önálló tápellátás mellett, kisebb kapacitású akkumulátorok esetén is hosszú ideig képes müködni.

\subsection{A Raspberry Pi 4B számítógép}

A mérési leírásban részletezett módon, az érzékelők által mért adatokat a PSoC 5LP mikrovezérlő egy számítógépnek adja át feldolgozásra, amely a Raspberry Pi 4B egység.

Jelenleg a Raspberry Pi több verzióval is rendelkezik, melyek közül a jelfeltérképező robot megvalósításához a legújabb, Raspberry Pi 4B kerül felhasználásra. Ez a verzió az azt megelőzőkhöz hasonlóan, Wi-Fi 4-es és 5-ös verziót támogató WLAN interfésszel, 40 GPIO csatlakozóval és CSI/DSI (Camera Serial Interface / Display Serial Interface) portokkal is rendelkezik. Az előző verziókkal szemben:

- gyorsabb processzorral (Broadcom 2711, Quad-core Cortex-A72 64-bites SoC @ 1.5GHz),

- két USB 3.0-ás és két USB 2.0-ás porttal,

- Gigabites Ethernet interfésszel,

- 2db nagyfelbontású videót is kezelni képes microHDMI porttal,

- és LPDDR4 típusú RAM-val van felszerelve (a felhasznált típus 2GB memóriával rendelkezik) [4].

Ezen előnyök mellett, ára kifejezetten kedvező, a frissebb, előző típusokhoz közeli, így a robot felépítéséhez ez a modell kerül felhasználásra. Kis méretének köszönhetően a roboton való elhelyezés egyszerüen megoldható. A Raspberry Pi segítségével annak felszereltsége és a rajta futtatható Linux operációs rendszer miatt az autonóm navigáció, a hőtérkép elkészítése és ennek a felhasználó számára elérhetővé tétele egy eszközzel megoldható. A CSI port felhasználásával az eszközhöz könnyen csatlakoztatható egy kamera, amely a távirányítás megvalósításában nyújt segítséget. Az ez által felvett videót a közvetlen csatlakozásnak köszönhetően, a Raspberry Pi maga képes feldolgozni, majd a hőtérképpel megegyezően azt a felhasználó számára elérhetővé tenni. 


\subsection{A Raspberry Pi Kamera Modul V2}

A roboton, annak érdekében, hogy távirányítás esetén a felhasználónak ne legyen szükséges a robot közelében tartózkodnia, és annak mozgását saját szemével követnie, egy kamera kerül elhelyezésre. Kifejezetten a Raspberry Pi számítógépekhez a Raspberry Pi Foundation egy kamera modult fejlesztett $\mathrm{ki}$, amelynek V2-es verziója kerül fel a robotra.

A kamera által készített fénykép felbontása 3280 x 2464 képpont, videó készítő képessége különböző felbontások mellett változik:

- $1080 \mathrm{p}$ esetén $-30 \mathrm{kép} / \mathrm{mp}$,

- $720 \mathrm{p}$ esetén - $60 \mathrm{kép} / \mathrm{mp}$,

- 640x480 esetén $-90 \mathrm{kép} / \mathrm{mp}$.

A robotra abból az okból kifolyólag kerül fel a modul frissebb verziója, mert annak ára megegyezik a V1-es verzióéval, felbontása azonban, a benne található Sony IMX219 szenzornak köszönhetően 5MP helyett 8MP [5].

A modul használatának előnye, hogy a számítógép CSI portját használva egy szalagkábellel csatlakozik ahhoz, ezzel lehetővé téve a nagysebességü adatátvitelt. A kiválasztott modul használatának előnye továbbá, hogy mérete és súlya csekély (mérete $25 \mathrm{~mm}$ x $23 \mathrm{~mm}$ x $9 \mathrm{~mm}$, súlya $3 \mathrm{~g}$ ), így a robotra való elhelyezése lényegesen egyszerübb más, nagyobb modulokhoz képest.

\subsection{Az ESP07 Wi-Fi modul}

Annak érdekében, hogy a vizsgálni kívánt WLAN Access-Point jelének erősségét a robot gyorsan, és megbízható módon legyen képes lemérni, egy Wi-Fi modul használata szükséges. Amennyiben a jelfeltérképezés elvégzéshez Wi-Fi modulok kerülnek felhasználásra, a robot képes az összes számára elérhető jelet lemérni, valamint több modul felszerelésével egy adott pontban a jelek erőssége akár több magasságon is megmérhető.

A robot megvalósításához számos különböző típusú Wi-Fi modul felhasználása lehetséges, melyek mindegyike képes a jelek RSSI paraméterét a robot számítógépének számára biztosítani. A robot elkészítéséhez az ESP-07-es Wi-Fi modul kerül felhasználásra.

A kiválasztott modul egy ESP8266EX típusú SoC-ot tartalmaz, amelyet kifejezetten hely-, és energiakorlátos felhasználási területekre fejlesztette ki az Ai-thinker Team. Az SoC, beállításaitól függően önmagában képes egy hálózatot üzemeltetni, vagy a Wi-Fi kommunikáció megvalósításához szükséges feladatokat ellátni egy másik, már egyéb feladatokat végző vagy Wi-Fi kommunikációra nem képes eszköz helyett. Az ESP8266EX SoC egyebek közt egy jelerősítőt, egy RF átalakítót és szürőket is tartalmaz, minimális PCB területen. A SoC csak a $802.11 \mathrm{~b} / \mathrm{g} / \mathrm{n}$ szabványon alapuló Wi-Fi típusokat támogatja, tehát csak 2,4 GHz-es jel mérhető vele [6].

A robot elkészítéséhez több ok miatt is ESP típusú modul kerül felhasználásra. Ezen modulok számos más beszerezhető típussal szemben jelentősen alacsonyabb árral rendelkeznek és a méréshez szükséges funkciókat pedig megfelelően képesek ellátni. A kiválasztott ESP-07-es modul mérete $(16 \mathrm{~mm} \times 21.2 \mathrm{~mm}$ $\mathrm{x} 3 \mathrm{~mm}$ ) pedig lehetővé teszi, hogy abból, a roboton, a kis rendelkezésre álló hely mellett is több darab elhelyezhetö legyen.

A modulok az általuk gyüjtött adatokat a PSoC-nak adják át további feldolgozásra. A modulok által szerzett információ soros kommunikációval érhető el. 


\subsection{Az ultrahangos távolságérzékelők}

A robot navigációját a rajta található Raspberry Pi 4B számítógépen futó ROS (Robot Operating System) program végzi. A navigációs algoritmus számára számos, szenzorokból érkező adat szükséges az ideális útvonal kiválasztásához. A két fö adat, amelyre a rendszernek szüksége van:

- a robot környezetében található tárgyak helyzetéröl kapható információk, amellyel lézeres letapogatók, vagy távolságérzékelők szolgálhatnak,

- a robot orientációja, amellyel IMU (Inertial Measurement Unit) szolgál [7].

Az említett módon, a környezetben található tárgyakról többféleképpen is gyüjthet a robot adatokat. A ROS navigációs rendszerek leggyakoribb megvalósításaiban ezen adatokat egy lézeres letapogató gyüjti be. A könnyebb és olcsóbb megvalósítás érdekében ehelyett távolságérzékelők kerülnek a robotra. Az érzékelők hátránya, hogy így lényegesen kisebb területet képes majd a robot „letapogatni” maga előtt, azonban azok energiaigénye és mérete jelentősen kisebb, használatuk lényegesen egyszerübb, amennyiben pedig meghibásodnak, könnyebben pótolhatók.

A robot megvalósításához kétfajta távolságérzékelő jelent ideális megoldást: a lézeres és az ultrahangos típusú. Lézeres távolságérzékelők használatával ugyan a tárgyak pontosabban bemérhetők, azonban ezek az érzékelők az ultrahangos típusúakkal szemben jelentősen drágábbak, és könnyebben sérülnek, ebből kifolyólag a robotra ultrahangos távolságérzékelők kerülnek.

Az UH távolságérzékelőkkel való távolság meghatározása a „repülési időn” (TOF, azaz Time of Flight) alapszik. A szenzor ultrahangot bocsát ki, majd pedig méri az időt, ameddig az általa kibocsátott hang a tőle adott távolságra levő tárgyról visszaverődik, és hozzá visszaér. Ezen idő meghatározásával a tárgy és a szenzor közti távolság egy egyszerü képlettel meghatározható:

$$
\mathrm{s}=\mathrm{v} \cdot \mathrm{t}
$$

ahol:

- s: a szenzor és a tárgy távolsága (méterben),

- v: a hang sebessége $(340 \mathrm{~m} / \mathrm{s})$,

- $\mathrm{t}$ : a szenzor által visszaadott repülési idő (másodpercben) [8].

Az egyik legkönnyebben beszerezhető, megfelelő pontossággal rendelkező, olcsó ultrahangos érzékelő típus, a HC-SR04-es szenzor. A szenzor „Trigger” lábára egy 10 $\mu$ s hosszú magas jelet adva az érzékelö $8 \mathrm{db} 40 \mathrm{kHz}$-es pulzust ad le, majd az „Echo” lábán a repülési időnek megfelelő szélességü impulzust ad ki. Az ideális müködéshez ajánlott, hogy a „Trigger” jel periódusideje 60 ms legyen [9].

Mivel a robot esetében a szenzor jelét feldolgozó PSoC GPIO-ira kapcsolható jel feszültsége nem haladhatja meg a 3,3V-ot, így a modul használatához a bekötés előtt a szenzor kimenetén megjelenő jel feszültségének 5V-ról 3,3V-ra való lecsökkentése elengedhetetlen. A roboton mindez egy $330 \Omega$-os és egy $470 \Omega$-os ellenállás felhasználásával elvégzett feszültségosztással valósul meg.

\subsection{Az MPU-9250 IMU szenzor}

A ROS navigációs rendszernek a robot mozgásával asszociált adatokra is szüksége van, így például a robot orientációjára. Ezen adatokat egy IMU képes a rendszernek szolgáltatni.

Az IMU szenzorok három fő elemből tevődnek össze:

1. Gyorsulásmérő: a mozgás során a robot gyorsulásának meghatározására.

2. Giroszkóp: a mozgás során tett szögelfordulás és szögsebesség mérésére.

3. Magnetométer: az eszközre ható mágneses mező erősségének mérésére [10].

A gyakorlatban a robotok navigációs rendszeréhez általánosan használt IMU szenzor típus az MPU9250, amely a jelerősségmérő robot autonóm navigációjának megvalósításához is felhasználásra kerül. 
Minden mérést követően a szenzor 9 adatot közöl:

- Az X, Y, Z irányú gyorsulást (mértékegysége: [g]).

- Az X, Y, Z irányú szögsebességet (mértékegysége: [\%/sec]).

- Az X, Y és $Z$ irányú mágneses mező erősségét (mértékegysége: [ $\mu \mathrm{T}]$ ) [11].

Az MPU-9250 szenzor előnye, hogy a navigációs rendszer számára, a robot mozgásával és annak irányával kapcsolatos minden információt képes mérni, amelyek $\mathrm{I}^{2} \mathrm{C}$ kommunikációval egyszerre elérhetőek, ezzel lényegesen egyszerübbé téve azok feldolgozását. Emellett kis mérete miatt a helykorlátos jelerősség mérö robotra akadálymentesen felhelyezhető.

\subsection{A HC-05 Bluetooth modul}

A robot vezérlése távirányítás esetén Bluetooth kommunikáción keresztül, egy vezérlőpanelról érkező irányok és sebességértékek segítségével történik. A kommunikációt két, egymással összepárosítható HC-05-ös Bluetooth modul valósítja meg.

A minimális késéssel történő kommunikációhoz mindkét modul full-duplex módban üzemel, a vezérléshez szükséges adatokat pedig a hozzájuk kötött mikrovezérlők állítják elö, és fogadják, elöre meghatározott módon. A vezérlőpanel adatai csak abban az esetben kerülnek küldésre, amennyiben az előző küldés során közölt értékek megváltoztak. A vezérlés adatait fogadó modul mikrovezérlője, amennyiben a kapott adatok bitsora a beállított követelményeknek nem felel meg (például a bitsor túl rövid, vagy a helyes kommunikációt jelző bitek nem megfelelőek), ismételt küldést kér a vezérlö paneltól. Ezzel a módszerrel biztosítható, hogy az irányok és sebességek megváltoztatására való szándékot a robot szinte azonnal megkapja és feldolgozza, mivel így a modulok elegendő időt kapnak az adatküldő és adatfogadó módok közti átváltásra.

A HC-05-ös modul az IEEE 802.15.1-es szabványosított protokollját használja, tehát a 2,4 GHz-es frekvenciatartományban üzemel. Hatótávolsága kevesebb, mint 100 méter, zajos környezetben azonban 30-40 méternél messzebb gyakoribbá válik az adatcsomagok hibás továbbítása. A modul elönye, hogy kis méretü, alacsony energiaigényü, könnyen használható és TTL kompatibilis, utóbbinak köszönhetően az általa adott jeleket GPIO-ra való bekötés előtt nem kell átalakítani [12].

\section{A robot szoftvere}

A jelfeltérképező robot rendszere a két központi szerepet betöltő egységen futó programokon alapszik. A robot autonóm navigációját, az érzékelők adatainak tárolását, valamint a hőtérkép elkészítését és annak a felhasználóhoz juttatását a Raspberry Pi 4B-n futó ROS (Robot Operating System) program valósítja meg. A szenzorok adatainak gyüjtéséért, majd azok alapszintű feldolgozásáért, az akkumulátor töltöttségének figyeléséért és a navigációs algoritmus és a távirányítás által adott vezérlési paramétereknek megfelelően a motorok müködtetéséért pedig a PSoC mikrovezérlő és az azon futó program felelös.

\subsection{Robot Operating System - ROS}

\subsubsection{Autonóm navigáció}

A mobil robot önálló navigációja a ROS framework-ben elérhető Husky navigáción alapszik. Ez a navigációs típus mozgás közben térképet készít a környezetéről, majd ennek használatával a bejárható területen önállóan navigál. A környezetében levő statikus tárgyak mellett a mozgó akadályokat is képes felismerni, és azoknak megfelelően mozogni. A Husky navigáció a térkép elkészítéséhez Gmapping-et 
használ. Ez egy ROS framework-ben implementálható node (független program), amely távolságérzékelők használatával SLAM algoritmust futtat le [13].

A SLAM (Simultaneous Localization and Mapping) lehetővé teszi a robot számára, hogy a környezetét feltérképezze (mapping), és hogy megállapítsa, hogy ezen környezetben hol helyezkedik el (localization). A ROS framework képes számos SLAM algoritmus, mint például a Gmapping, a Hector SLAM és a CoreSLAM implementálására is [14].

Az ezen navigációs típus használatának előnye, hogy az algoritmusnak szükséges érzékelő adatokat egyszerüen alkalmazható, könnyen beszerezhető szenzorok képesek szolgáltatni. Emellett az algoritmus használata a ROS framework-ben, a megfelelö csomagok implementálásával lényegesen leegyszerüsödik.

Amennyiben valamilyen okból kifolyólag a felhasználó autonóm navigáció helyett távirányítással akarja irányítani a robotot, úgy a Raspberry által adott paraméterek helyett a PSoC a vezérlőpaneltól kapott adatokat veszi figyelembe a motorok irányításához. Ebben az esetben, a terület térképe a navigációs algoritmusokkal szintúgy elkészíthető, mivel az érzékelők adatai továbbra is rendelkezésre állnak.

\subsubsection{A hötérkép elkészitése}

A navigációs rendszer által elkészített térképet alapul véve a ROS framework-ben implementálható Heatmap csomag képes a lemért Wi-Fi jelerősségek alapján egy hőtérkép elkészítésére.

A mérés elvégzéséhez a Heatmap csomagnak szüksége van egy térképre, amely a mérendő területről készült. Ennek elkészítéséért a már előbb részletezett navigáció felel. A Wi-Fi modulok által mért adatokat egy adatfolyamként publikussá téve, a Heatmap node hozzá tud férni a számára szükséges értékekhez. A mérés közben képes a térképen, a robot aktuális helyzetéhez kapcsolódó jelerősséget nagyságának megfelelő színkóddal - megjelölni [15].

A program az elkészített hőtérképet PNG formátumban a felhasználó számára elérhetővé teszi. A PNG használatának oka, hogy ezen formátum a kép online megtekintéshez, többek között a JPEG formátumhoz képest, jól használható, az átvitelekor történő hibák könnyen érzékelhetőek. A PNG a nagy, egyszínü területeket tartalmazó képek (például hőtérképek) feldolgozásakor és tárolásakor is előnyös, mivel adatvesztés mentes tömörítést tesz lehetővé.

Amennyiben az elkészített térkép hibás, tehát vagy a mérés vagy pedig a feldolgozás esetén hiba történt, a teljes mérés megismétlése nélkül, a térkép javítható. Ebben az esetben a robot a hibás adattal rendelkező koordinátához a navigációs rendszer segítségével képes eljutni, a mérést megismételni, és a térképet kijavítani. A felhasználó számára elérhetővé tett térkép folyamatosan frissítésre kerül, így amennyiben az adott, újra vizsgálni kívánt területen a robot távirányítás közben áthalad, úgy a helyes adatokkal a térkép frissül.

\subsubsection{Az adatok tárolása és a webszerver}

A mérés során rögzített adatok a futó ROS programon keresztül a Raspberry számítógépen mentésre kerülnek, így amennyiben a mérés váratlanul félbe szakad, ezek az adatok a számítógép tárhelyén elérhetőek.

A felhasználó számára a robot a kamera képét, az akkumulátor töltöttségi szintjét, és az elkészített hőtérképet egy webszerveren keresztül teszi elérhetővé. A webszerver alapját az Automatizálási és Infokommunikációs intézetben található Kuka Robot V2 webszervere adja, amelyet Molnár István diplomamunkájaként készített el [16]. 


\subsection{A PSoC Creator és a PSoC-on futó program}

A robot megvalósításában használt PSoC-nak számos, a fejezet elején felsorolt feladata van. Az ezek elvégzését lebonyolító program a PSoC Creator szoftver segítségével készül el. Fontos megjegyezni, hogy a PSoC Creator fejlesztőkörnyezetben a mikrovezérlő használni kívánt analóg és digitális perifériáit elöbb egy kapcsolási rajzon, szimbólumként kell elhelyezni, majd be kell állítani azok megfelelö tulajdonságait, és ezt követően egy $\mathrm{C}$ program formájában meghatározni azok müködését.

\subsubsection{A program kapcsolási rajza és a program feladata}

A jelfeltérképező robot esetén az ROS programhoz képest a PSoC jelentősen egyszerübb firmware-t használ a müködéshez. A PSoC 5LP-n rendelkezésre álló digitális és analóg tömbök közül csak kevés számú kerül felhasználásra. A blokk diagramra a következő elemek kerülnek:

- A távirányításhoz használt Bluetooth modulhoz szükséges UART blokk.

- Az IMU szenzorral való kommunikációhoz szükséges I2C (master) blokk.

- Az ESP-07 modul(ok) beállításához és adatainak gyüjtéséhez szükséges UART_esp blokk.

- Az ultrahangos szenzor „Trigger” jelének elöállításához szükséges PWM blokk.

- Az ultrahangos szenzor „Echo” jelének méréséhez szükséges Counter (számláló) blokk.

- A motorok léptetéséhez, a PWM és a Counter blokkok számlálóinak müködéséhez szükséges Órajel szimbólumok.

- A Raspberry Pi-vel való kommunikációhoz szükséges USBUART blokk.

- A tápegység töltöttségi szintjének méréséhez szükséges SAR ADC (Successive Approximation Analog-to-Digital Converter) blokk.

- Digitális bemeneti és kimeneti pin-ek.

A szimbólumokkal elkészített kapcsolási rajzot a 2. ábra mutatja.

A motorok müködtetéséhez egy $700 \mathrm{~Hz}$-es órajel szükséges. Ennél nagyobb frekvenciájú léptetés esetén ugyan a motorok képesek nagyobb sebességgel forogni, azonban ilyen gyors léptetés mellett az irányváltások során gyakorivá válik a motorok elakadása. A „Trigger” jelet előállító PWM blokk órajele 4 kHz-es, ezzel biztosítható az ultrahangos érzékelök megfelelő müködéséhez szükséges $60 \mathrm{~ms}$ periódusidejű jel. Azt az időt, ameddig az „Echo” jel magas állapotban van, a Counter blokk méri meg. Ez a blokk egy $10 \mathrm{kHz}$-es órajellel rendelkezik, így az időintervallum megfelelő pontossággal megmérhetö.

Egyes blokkok müködésének engedélyezéséhez azok „reset” bemenetére egy alacsony logikai jelszint bekötése szükséges, amelyet a „0” jelzésű szimbólum biztosít.

Az egy-egy pin-re kerülő adat kétféleképp is meghatározható: hardveres összeköttetéssel, vagy szoftveres úton. Hardveres összeköttetés esetén a pin-en a hozzá csatlakoztatott elemek által generált adatok jelennek meg. Ilyen módon kerül az:

- I2C (,sda” és „sdl” pinek”),

- az UART (,Rx” és „Tx” pinek),

- az UART_esp („Rx_esp” és „Tx_esp” pinek),

- a PWM (,trigger" pin),

- az ADC (,akku” pin),

- a motorokat léptető „lepes” órajel blokk (,step” pin) jele is bekötésre.

A C nyelven megírt program alapján generált adatok szoftveres úton, a PSoC Creator saját függvényeivel írhatók a pin-ekre. Ilyen módon kerül adat a következő pinekre:

- A „LED”: A sikeres bluetooth kommunikációt mutatja.

- Az „irany_j” és ,irany_b”: A robot mozgásának irányát adják a motorvezérlő áramköröknek. 
- Az „enable b” és „enable j”: A robot mozgásának tiltását és engedélyezését végzik.

- Az „ms2 b” és „ms 2 j”: A mozgás során a kanyarodás megvalósításáért felelnek. Amennyiben igazak, úgy a nekik megfelelő bal vagy jobb oldali motorok fele akkora sebességgel forognak.

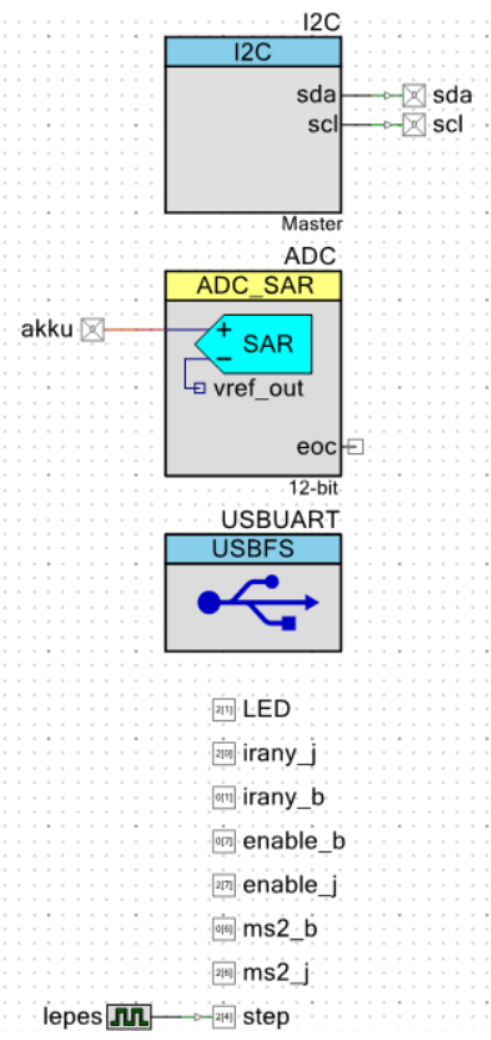

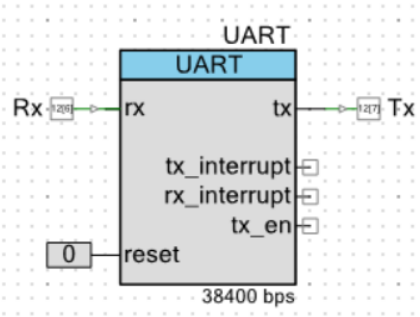
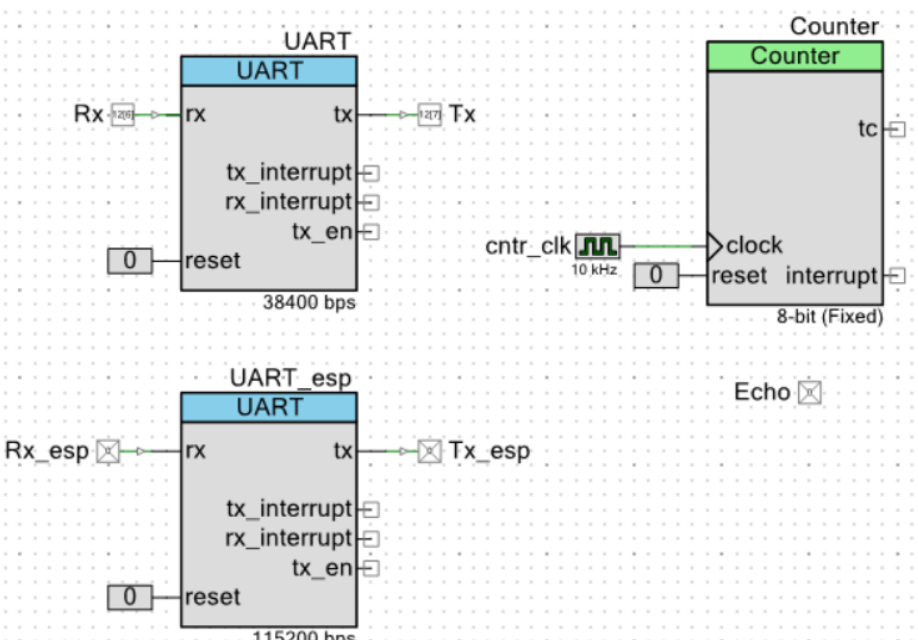

\section{2. ábra. A program kapcsolási rajza}

Az ultrahangos érzékelő „Echo” jele egy digitális bemeneti pinre kerül bekötésre, amelyet a C program olvas majd ki. Ennek az értéknek megfelelően indul majd el és áll meg a Counter blokk számolása.

Amennyiben a robotra több ultrahangos érzékelő kerül, úgy a különböző „Echo” jelek megfelelő méréséhez több Counter blokk és „Echo” pin szükséges. Hasonlóan, több ESP modul használata esetén a velük való kommunikáció megvalósításához és az adatok gyüjtéséhez több UART_esp blokk, „Rx_esp” és „Tx_esp” pin szükséges.

A pin-ek és a kártya különböző lábai közti összeköttetések a fejlesztőkörnyezet egy másik, „Pins” nevü paneljén állíthatóak be.

A jelfeltérképező robot esetén a kód:

- Elvégzi a dolgozatban már említett módon a bluetooth kommunikációt.

- Távirányítás esetén a bluetooth kommunikációval kapott adatok szerint müködteti a motorvezérlö áramkörök lábait.

- Adatokat gyüjt az IMU és UH szenzoroktól, melyek közül utóbbi adatait átszámolja a repülési időről távolsággá. 
- Jelerősség értékeket gyüjt az ESP modul(ok)tól.

- Az akkumulátor töltöttségi szintjét jelző, az ADC blokk által adott értékeket százalékos formába alakítja át.

- A gyüjtött és feldolgozott adatokat továbbítja a Raspberry Pi-nek további használatra.

- Autonóm navigáció esetén a Raspberry-től kapott vezérlési adatoknak megfelelően irányítja a motorvezérlő áramköröket.

\section{7. Összefoglalás}

A robot megtervezésének célja egy olyan jelerősség feltérképező eszköz létrehozása, amely megkönnyíti akár közintézményekben, akár otthonokban, akár ipari területeken a Wi-Fi hálózatok jelerősségének megmérését, a mérési eredményeket pedig egy könnyen és gyorsan megérthető módon a felhasználó számára elérhetővé teszi.

A tervezés folyamán felkutatásra kerültek a Wi-Fi jelerősség mérésének alapjai, az RSSI paraméter, és az ennek rögzítését lehetővé tevő, jelenleg is elérhetö eszközök. Ezt követően sor került a jelenlegi eszközök hátrányait leküzdő, és egyéb fontos elvárásoknak eleget tevő mérési eszköz, a jelerősség feltérképező mobil robot meghatározására.

A robot megvalósításához előbb rendszerének váza került megtervezésre, majd annak fizikai összeállításához szükséges eszközök kerültek kiválasztásra, melyek pontos funkciói, használatuk előnyei és hátrányai is felsorolásra kerültek. A fizikai megvalósítást követően a robotot müködtető szoftveres részek szerkezete is meg lett határozva, mely később bővítésre került a mikrovezérlőn futó program részletes tervével.

A robot megvalósításához szükséges elemek és az azokat müködtető programok megtervezése során jelentős figyelmet élvezett a használni kívánt alkatrészek beszerzési költsége, elérhetősége és felhasználásuk nehézsége is. A cél ezzel az volt, hogy egy jó minőségü, könnyen és megfizethető áron elkészíthető feltérképező eszköz kerüljön megtervezésre.

A megtervezett roboton számos fejlesztési lehetőség adott, melyek közül a legfontosabb a távirányítás Bluetooth helyett Wi-Fi-vel történő megvalósítása, mellyel a távirányítás hatótávolsága jelentősen megnőne és stabilabbá válna.

\section{Köszönetnyilvánítás}

A cikkben ismertetett kutató munka az EFOP-3.6.1-16-2016-00011 jelü „Fiatalodó és Megújuló Egyetem - Innovatív Tudásváros - a Miskolci Egyetem intelligens szakosodást szolgáló intézményi fejlesztése" projekt részeként - a Széchenyi 2020 keretében - az Európai Unió támogatásával, az Európai Szociális Alap társfinanszírozásával valósul meg.

\section{Irodalom}

[1] Nakprasit, K., Phongcharoenpanich, C.: Investigation of received signal strength of IEEE 802.11n WLAN in coverage of Nakhon Ratchasima Rajabhat University, IEEE, 2018. https://doi.org/10.1109/ECTICon.2018.8620018

[2] Understanding WiFi signal strength, [Online].

Elérhető: https://www.metageek.com/training/resources/wifi-signal-strength-basics.html

[3] 32-bit Arm ${ }^{\circledR}$ Cortex ${ }^{\circledR}-M 3$ PSoC ${ }^{\circledR} 5$ LP - Overview \& Products, [Online].

Elérhetö: https://www.cypress.com/products/32-bit-arm-cortex-m3-psoc-5lp 
[4] Raspberry Pi 4 Tech Specs, [Online].

Elérhetö: https://www.raspberrypi.org/products/raspberry-pi-4-model-b/specifications/

[5] Camera module - Hardware specification, [Online].

Elérhetö: https://www.raspberrypi.org/documentation/hardware/camera/

[6] ESP-07 WiFi Module - Version 1.0, [Online].

Elérhető: https://www.mikrocontroller.net/attachment/338570/Ai-thinker_ESP-

07_WIFI_Module-EN.pdf

[7] Navigation - Package summary, [Online].

Elérhetö: http://wiki.ros.org/navigation

[8] Ultrahangos méréstechnika, [Online].

Elérhetö: https://www.magyar-elektronika.hu/10005-tartalom/2377-ultrahangos-merestechnika

[9] Ultrasonic ranging module HC - SRO4, [Online].

Elérhetö: https://cdn.sparkfun.com/datasheets/Sensors/Proximity/HCSR04.pdf

[10] What is an IMU?, [Online]. Elérhető: https://www.spartonnavex.com/imu/

[11] MPU-9250 Product specification - Revision 1.0, [Online]. Elérhető: https://cdn.sparkfun.com/assets/learn_tutorials/5/5/0/MPU9250REV1.0.pdf

[12] HC-05 - Bluetooth module, [Online].

Elérhető: https://components101.com/wireless/hc-05-bluetooth-module

[13] navigation, [Online]. Elérhető: http://wiki.ros.org/navigation

[14] Megalingam, R. K., Teja, C. R., Sreekanth, S., Raj, A.: ROS based autonomous indoor navigation simulation using SLAM algorithm, 2018. [Online]. Elérhetö:

https://www.researchgate.net/publication/337465619_ROS_based_Autonomous_Indoor_ Navigation_Simulation_Using_SLAM_Algorithm

[15] Heatmap, [Online]. Elérhetö: http://wiki.ros.org/heatmap

[16] Molnár, I.: Teljes körü webes vezérlö felület tervezése autonóm mobil robot rendszerhez, Diplomamunka, Miskolci Egyetem, Automatizálási és Infokommunikációs Intézet, 2018. 